\title{
Evaluation of Soil Properties under Different Forests in Mid Hills of Himachal Himalayas
}

\author{
Vijeta Thakur ${ }^{1}$, Mohan Singh ${ }^{2 *}$, Satish Kumar Bhardwaj ${ }^{3}$ \\ ${ }^{1}$ Student, Department of Environmental Science, Dr. YS Parmar University of Horticulture \& Forestry, Solan (HP), India \\ ${ }^{2}$ Senior Scientist, Department of Environmental Science, Dr. YS Parmar University of Horticulture \& Forestry, Solan (HP), \\ India \\ ${ }^{3} \mathrm{HOD}$, Department of Environmental Science, Dr. YS Parmar University of Horticulture \& Forestry, Solan (HP), India
}

*Address for Correspondence: Dr. Mohan Singh, Senior Scientist, Department of Environmental Science, Dr. YS Parmar University of Horticulture \& Forestry, Nauni-173 230 Solan (HP), India

E-mail: jangra ms@live.com

Received: 22 Mar 2020/ Revised: 31 May 2020/ Accepted: 25 Aug 2020

\begin{abstract}
Background: The soil properties majorly depend upon the soil organic matter encompasses as it represents the wide ranging carbon reserves in the earth's environment have followed $11 \%$ of soil organic carbon in forest soils around the world; hence, the present was conducted under seven forests in mid-hills of Himachal Himalayas during 2019-20.

Materials: The soil samples from three deeps were collected $(0-20,20-40$ and $40-60 \mathrm{~cm})$ under seven selected forests viz. northern dry mixed deciduous forests, Himalayan Chir pine forest, ban oak forest, moist deodar forest, Mohru oak forest, lowlevel blue pine forest and Kharsu forest at four locations. The properties like soil organic carbon content, bulk density, coarse fragments and soil organic carbon stock were evaluated.

Results: The soil organic carbon was highest $\left(32.3 \mathrm{~g} \mathrm{~kg}^{-1}\right)$ under Kharsu, bulk density $\left(1.12 \mathrm{Mg} \mathrm{m}^{-3}\right)$ and coarse fragments $(37.4 \%)$ under Mohru forests. The Kharsu forests contained the highest (41.4 Mg C ha-1) whereas Northern dry mixed deciduous forests lowest (16.6 Mg C ha-1) soil organic carbon stock. The contribution of deodar forests towards the total Soil organic carbon (SOC) pool of the study area was $46.32 \%$ followed by $23.24,15.7,6.14,5.89,1.64$ and $1.03 \%$ by chir pine, blue pine, ban oak, kharsu, and mohru oak and northern dry mixed deciduous forests, respectively.

Conclusion: The soil organic carbon was highest under Kharsu, bulk density and coarse fragments under Mohru forests and highest organic carbon stock under deodar forests. A decreasing trend in organic carbon, carbon stock and increase in bulk density \& course fragments was observed with depth.
\end{abstract}

Key-words: Forests, Mid hills, Properties, Soil, Soil organic matter (SOM)

\section{INTRODUCTION}

The soil properties majorly depend upon the soil organic matter (SOM) enclosing all organic constituents in the soil and is traditionally divided into "dead" and "living" components whereas SOC is the carbon component of SOM. Soils are the main carbon reserves in the terrene ecosystem, with 11 per cent of organic soil content in forest soils ${ }^{[1,2]}$.

\section{How to cite this article}

Thakur V, Singh M, Bhardwaj SK. Evaluation of Soil Properties under Different Forests in Mid Hills of Himachal Himalayas. SSR Inst. Int. J. Life Sci., 2020; 6(5): 2660-2666.

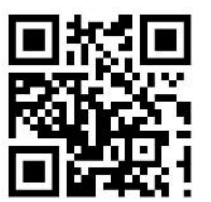

Access this article online https://iijls.com/
Globally, forests store significant quantities of carbon sequestered from the environment and stored in living and non-living biomass and soil ${ }^{[3,4]}$. More than 40 per cent of the carbon in soil is contained underneath forests.

The carbon pools of forest soils are not well understood compared with the carbon pools above ground ${ }^{[5,6]}$. The huge spatial variations in organic forest soil also restricted the ability to predict its spatial distribution $[4,7,9]$. For soil quality assessments, inventory analysis and soil organic carbon exploration is needed ${ }^{[10,11]}$ and carbon cycling predictions ${ }^{[12]}$, which are worthy tools for state and regional planning ${ }^{[13,14]}$. Physical properties of soil like structure, texture, particle size, composition are affected by agrarian activities, dominating tree species and the site characteristics ${ }^{[15]}$. 
Considering that, the present research was planned to assess the soil properties under different forests in midhills of Himachal Himalayas focused on the organic form of carbon under different forests.

\section{MATERIALS AND METHODS}

Study area location- The present investigation was carried in the Department of Environmental Science,
College of Forestry, Dr. Y S Parmar University of Horticulture and Forestry, Nauni, Solan (HP) by selecting seven different forest types of Mandi district falling in the mid-hill of Himachal Himalayas during 2019-20 (Fig. 1).

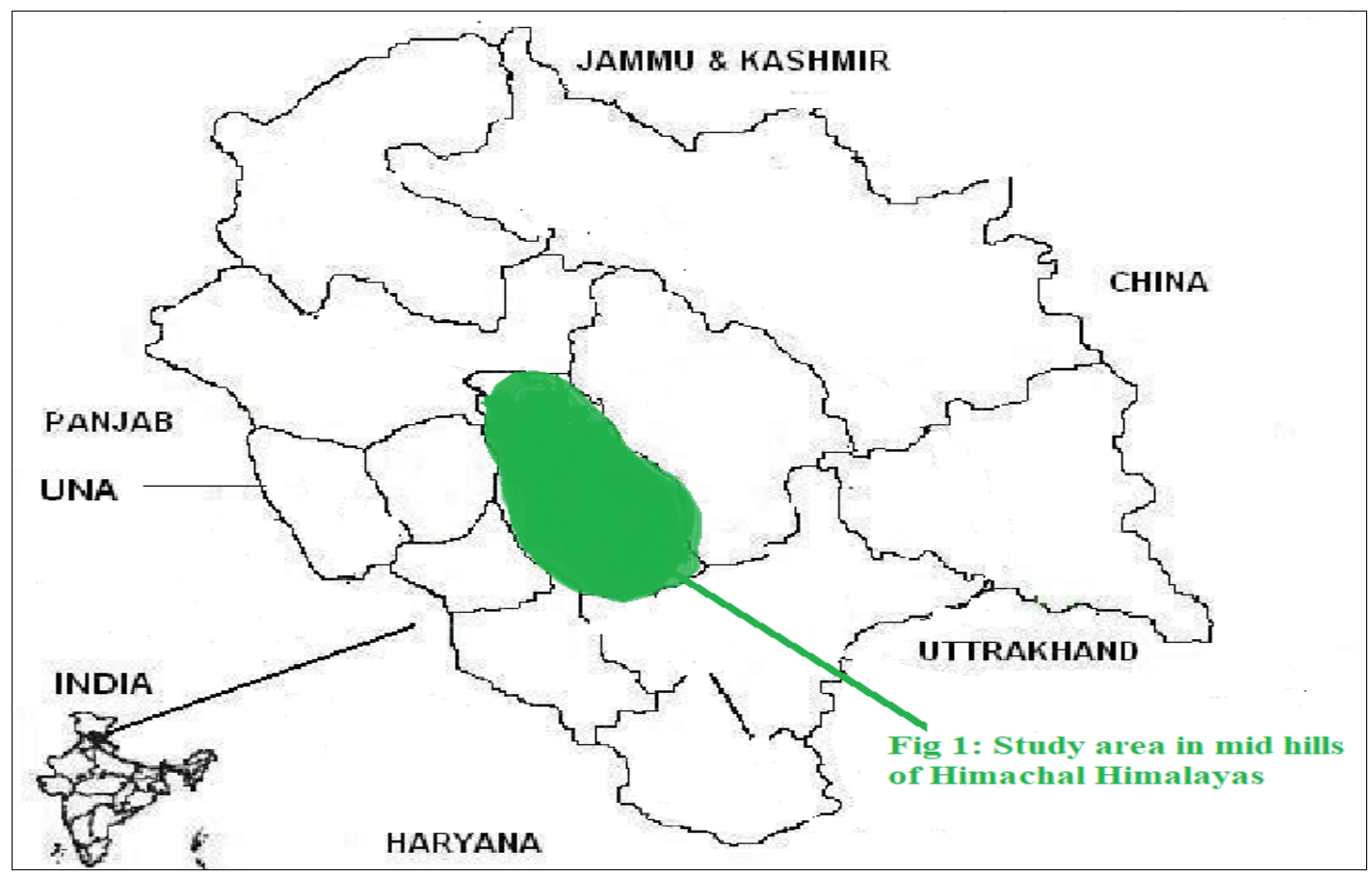

Fig. 1: Study area in mid hills of Himachal Himalayas

The geographic location of the study site was between $31^{\circ} 42^{\prime} 25^{\prime \prime}$ Northern latitude $76^{\circ} 55^{\prime} 54^{\prime \prime}$ East longitudes with altitude varies between $503 \mathrm{~m}$ to $4,034 \mathrm{~m}$ amsl with subtropical highland climate having hot summers and cold winters generally experiences rainfalls during end of the summer season. Temperatures typically range from $6.7^{\circ} \mathrm{C}$ to $39.6^{\circ} \mathrm{C}$ over a year. Monthly precipitation varies between $25.4 \mathrm{~mm}$ in November to $228.6 \mathrm{~mm}$ in August. The average total annual precipitation is $832 \mathrm{~mm}$.

Collection and Analysis samples- Seven different forests viz. Northern dry mixed deciduous forest, Himalayan chir pine forest, Ban oak forest, Mohru oak forest, Moist deodar forest, Low-level blue pine forest, Kharsu oak forests of the district were selected for the study. Based on spatial variations under each forest three prominent locations were identified which replicated thrice (Fig. 1). The soil samples from $0-20 \mathrm{~cm}, 20-40 \mathrm{~cm}$ and $40-60 \mathrm{~cm}$ depth were collected from the identified locations. The samples then brought to the soil analysis laboratory, air- dried under the shade, ground with wooden pestle mortar, passed through $2 \mathrm{~mm}$ sieve and further through $0.5 \mathrm{~mm}$ sieve and stored in cloth bags for analysis. SOC was determined by Gelman et al. ${ }^{[16]}$ method, bulk density was measured by core method ${ }^{[30]}$ and then the soil organic carbon ${ }^{[5]}$ stock ( $\mathrm{Mg} \mathrm{C} \mathrm{ha-1}$ ) was calculated by the following formula as:

\section{SOC $=[\mathrm{SOC}] \times$ Bulk Density $\times$ Depth $\times$ Coarse Fragments $\times$ 10}

Where,

SOC= Soil organic carbon stock for the soil of each forest, $\mathrm{Mg} \mathrm{Cha-1}$

[SOC]= Concentration of SOC in given soil mass, $\mathrm{g} \mathrm{C}(\mathrm{kg}$ soil) $^{-1}$, obtained from lab analysis

Bulk Density= Soil mass per sample volume, $\mathrm{Mg} \mathrm{m}^{-3}$ Depth= Sampling depth or thickness or soil layer $(\mathrm{cm})$

Coarse Fragments $=1-($ Volume of coarse fragments (\%)/ 100)

Being ration, it is dimensionless. 
The data generated thus, further statistically analyzed according to the Gomez and Gomez, ${ }^{[17]}$ procedure for randomized block design. The properties like soil organic carbon content ${ }^{[5]}$, bulk density ${ }^{[30]}$, coarse fragments ${ }^{[28]}$ and soil organic carbon stock ${ }^{[23]}$ were evaluated.

\section{RESULTS}

Variation of organic carbon- The highest content (33.9 g $\mathrm{kg}^{-1}$ ) of soil organic carbon was observed under Kharsu forests at $\mathrm{D}_{1}(0-20 \mathrm{~cm})$ depth followed by Deodar $(31.3 \mathrm{~g}$ $\left.\mathrm{kg}^{-1}\right)$ at the same depth. The lowest content $\left(10.2 \mathrm{~g} \mathrm{~kg}^{-1}\right)$ was recorded under northern dry mixed deciduous forests at $D_{3}(40-60 \mathrm{~cm})$ depth (Table 1$)$.

Table 1: SOC, SBD, SCF and SOCS distribution under different forest types at different depths

\begin{tabular}{|c|c|c|c|c|c|c|c|c|c|c|c|c|}
\hline \multirow{3}{*}{$\begin{array}{l}\text { Forest } \\
\text { types }\end{array}$} & \multicolumn{4}{|c|}{$\begin{array}{l}\text { Soil organic carbon (SOC) } \\
\qquad\left(\mathrm{g} \mathrm{kg}^{-1}\right)\end{array}$} & \multicolumn{3}{|c|}{$\begin{array}{c}\text { Soil bulk density (SBD) } \\
\left(\mathrm{Mg} \mathrm{m}^{-3}\right)\end{array}$} & \multicolumn{5}{|c|}{$\begin{array}{cc}\text { Soil coarse fragments Soil organic carbon } & \text { stock (SOCS) } \\
\begin{array}{cc}\text { (SCF) (\%) } & \left(\mathrm{Mg} \mathrm{Cha}^{-1}\right) \\
\end{array}\end{array}$} \\
\hline & \multicolumn{12}{|c|}{ Soil depth $(\mathrm{cm})$} \\
\hline & $\begin{array}{c}D_{1} \\
(0-20) \\
\end{array}$ & $\begin{array}{c}D_{2} \\
(20-40) \\
\end{array}$ & $\begin{array}{c}D_{3} \\
(40-60) \\
\end{array}$ & $\begin{array}{c}D_{1} \\
(0-20) \\
\end{array}$ & $\begin{array}{c}D_{2} \\
(20-40) \\
\end{array}$ & $\begin{array}{c}D_{3} \\
(40-60) \\
\end{array}$ & $\begin{array}{c}D_{1} \\
(0-20) \\
\end{array}$ & $\begin{array}{c}D_{2} \\
(20-40) \\
\end{array}$ & $\begin{array}{c}D_{3} \\
(40-60) \\
\end{array}$ & $\begin{array}{c}D_{1} \\
(0-20) \\
\end{array}$ & $\begin{array}{c}D_{2} \\
(20-40) \\
\end{array}$ & $\begin{array}{c}D_{3} \\
(40-60) \\
\end{array}$ \\
\hline $\mathrm{F}_{1}$ & 31.3 & 28.3 & 23.7 & 0.90 & 1.04 & 1.13 & 23.0 & 27.9 & 35.1 & 43.1 & 41.9 & 34.4 \\
\hline $\mathrm{F}_{2}$ & 21.8 & 18.8 & 15.3 & 0.95 & 1.07 & 1.19 & 33.1 & 37.0 & 39.9 & 27.9 & 26.0 & 22.2 \\
\hline $\mathrm{F}_{3}$ & 19.4 & 15.0 & 12.8 & 1.01 & 1.11 & 1.19 & 29.2 & 33.9 & 37.5 & 27.8 & 22.1 & 19.0 \\
\hline $\mathrm{F}_{4}$ & 20.8 & 18.3 & 16.4 & 1.01 & 1.09 & 1.18 & 24.0 & 26.9 & 29.7 & 32.0 & 29.3 & 27.2 \\
\hline $\mathrm{F}_{5}$ & 33.9 & 32.2 & 31.0 & 0.86 & 0.94 & 1.05 & 25.1 & 32.9 & 39.0 & 44.0 & 40.4 & 39.9 \\
\hline $\mathrm{F}_{6}$ & 14.9 & 13.5 & 12.1 & 1.01 & 1.12 & 1.24 & 35.8 & 37.2 & 39.2 & 19.2 & 19.1 & 18.5 \\
\hline $\mathrm{F}_{7}$ & 13.5 & 11.2 & 10.2 & 1.01 & 1.12 & 1.25 & 34.9 & 36.5 & 38.7 & 18.0 & 16.0 & 15.9 \\
\hline
\end{tabular}

F1= Deodar, F2= Blue Pine, F3= Chir Pine, F4= Ban Oak, F5= Kharsu Oak, F6= Mohru Oak, F7= Northern dry mixed deciduous

The descending trend in soil organic carbon among different forest types was observed as $F_{5}>F_{1}>F_{2}>F_{4}>F_{3}$ $>F_{6}>$ and $F_{7}$ (Fig. 2a). The amount of soil organic carbon was found highest in the uppermost soil layer and it was

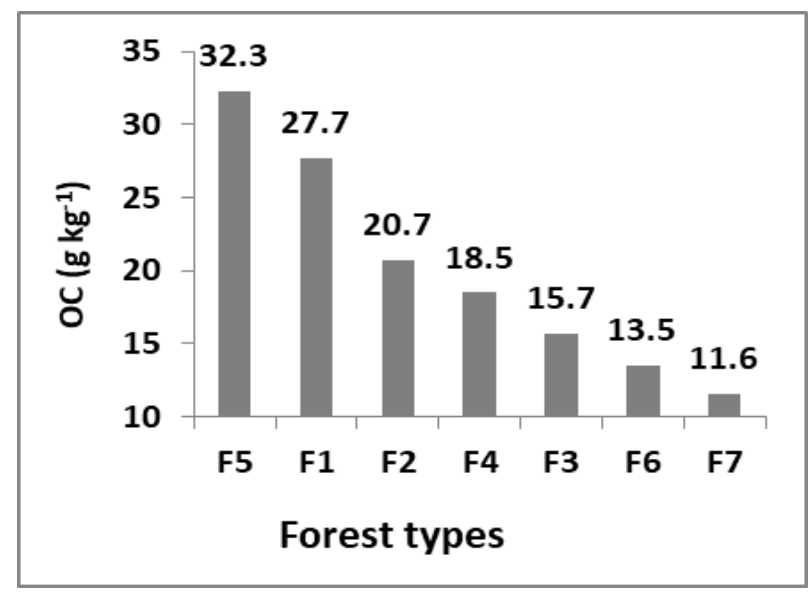

(a) continuously declining with rising depth across all types of forest. The decreasing rate was $2.4 \mathrm{~g} \mathrm{Kg}^{-1}$ per $20 \mathrm{~cm}$ of soil depth (Table 2), which was highly significant $\left(R^{2}=0.98\right)$.

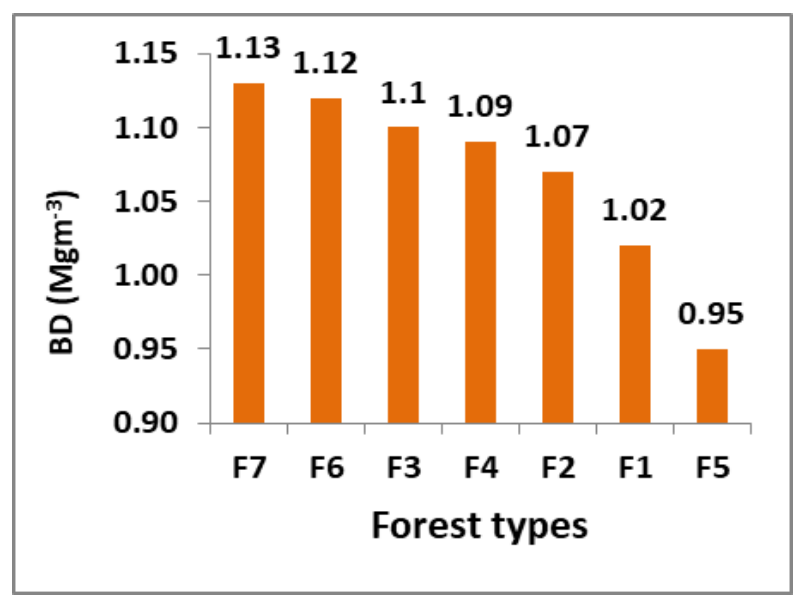

(b) 


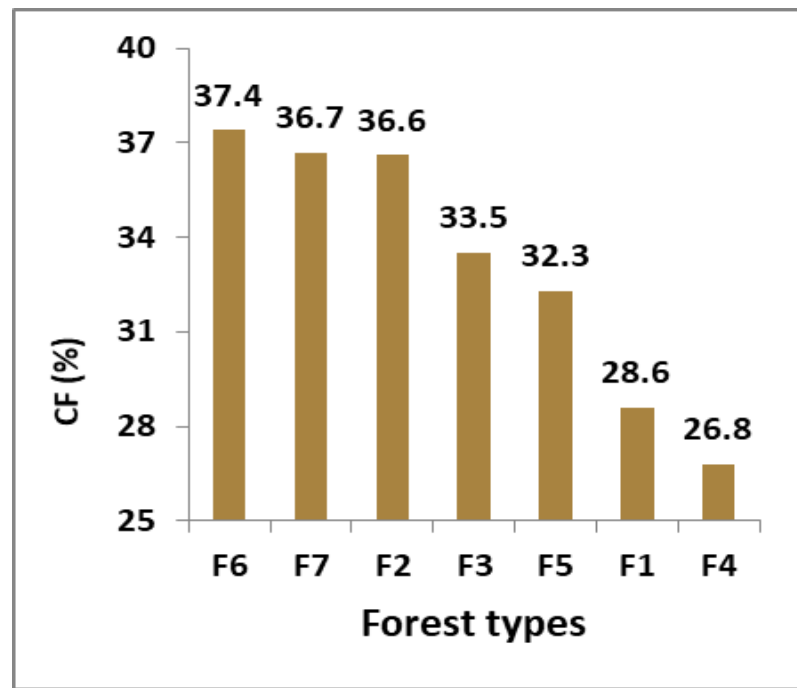

(c)

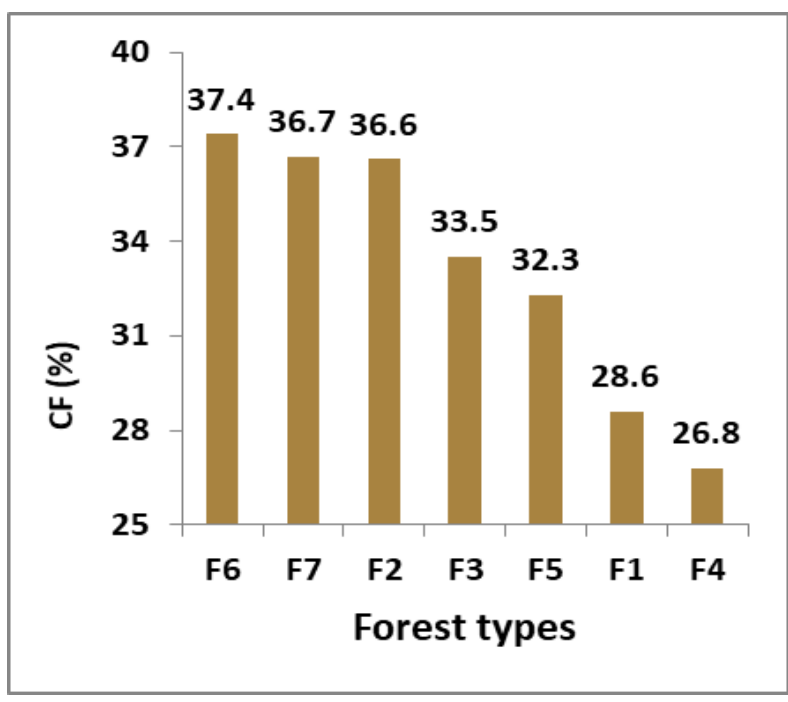

(d)

Fig. 2: Descending trend of soil organic carbon

(a) Bulk density (b) Coarse fragments (c) Organic carbon stock (d) Under different forests of Mandi district (HP)

Variation of bulk density (BD)- The soil bulk density of all the forests and depths was ranged from $0.86 \mathrm{Mg} \mathrm{m}^{-3}$ to $1.25 \mathrm{Mg} \mathrm{m}^{-3}$. It was found highest $\left(1.25 \mathrm{Mg} \mathrm{m}^{-3}\right)$ under northern dry mixed deciduous forests at 40-60 cm depth followed by Mohru forests $\left(1.24 \mathrm{Mg} \mathrm{m}^{-3}\right.$ ) at the same depth, whereas, lowest $\left(0.86 \mathrm{Mg} \mathrm{m}^{-3}\right)$ bulk density was observed under Kharsu forest at 0-20 cm depth followed by the same forest at $20-40 \mathrm{~cm}$ soil depth (Table 1 ). Among the different forest the descending trend in soil bulk density was observed as $F_{7}>F_{6}>F_{3}>F_{4}>F_{2}>F_{1}$ and $F_{5}$ (Fig. 2b). This increasing trend in soil bulk density indicated that the compaction of soil increases and hence the quality decrease with depth which may be due to that the organic contents were observed decreasing with depth. The mean soil bulk density under all the forests was continuously decreasing with depths at a rate of $0.10 \mathrm{Mg} \mathrm{m}^{-3}$ per $20 \mathrm{~cm}$ depth (Table 2), which indicated that the soil quality decreased with depth.

Table 2: Correlation statistics of SOC, SBD, SCF and SOCS with depth

\begin{tabular}{cccc}
\hline Soil parameters & Intercept & Rate & $\mathbf{R}^{\mathbf{2}}$ \\
\hline SOC & 24.6 & -2.45 & 0.98 \\
SBD & 0.86 & 0.105 & 0.99 \\
SCF & 25.4 & 3.85 & 0.98 \\
SOCS & 32.6 & -2.45 & 0.99 \\
\hline
\end{tabular}

$\mathrm{SOC}=$ Organic carbon, $\mathrm{SBD}=$ Bulk density, $\mathrm{SCF}=$ Coarse fragments, SOCS= Organic carbon stock
Variation of coarse fragments (CF)- The gravel contents of the soil under selected forest types and depth was found between 23.0 to 39.9 per cent. Up to $60 \mathrm{~cm}$ depth the highest coarse fragments were found under Mohru Forest (37.4\%) followed by Northern dry mixed deciduous forest (36.7\%) and the lowest (26.8\%) under Ban oak forest followed by Deodar forest (28.6\%) which was at par with Kharsu forest (Table 1). In respect of coarse fragments a descending order of different forest like $F_{6}>F_{7}>F_{2}>F_{3}>F_{5}>F_{1}>F_{4}$ was observed (Fig 2c). On an average, the soil coarse fragments under all the forests were continuously increasing with depths at a rate of $3.85 \%$ per $20 \mathrm{~cm}$ depth (Table 2), which indicated that the soil quality was decreasing with increasing soil depth.

Soil organic carbon stock (SOCS)- Exact estimation of SOC stocks is important in order to understand the connection between atmospheric and terrestrial carbon. The highest SOC stock (44.0 Mg C ha-1) was recorded under Kharsu oak forests followed by Deodar (43.1 Mg C $\mathrm{ha}^{-1}$ ) and the lowest (15.9 $\mathrm{Mg} \mathrm{Cha}^{-1}$ ) was under Northern dry mixed deciduous forests (Table 1 ) in uppermost soil layer $(0-20 \mathrm{~cm})$. The descending trend like: $F_{5}>F_{1}>F_{4}>$ $\mathrm{F}_{2}>\mathrm{F}_{3}>\mathrm{F}_{6}>\mathrm{F}_{7}$ was observed among different forests (Fig. 2d), which may be due to variability land use pattern and management practices ${ }^{[24]}$. The mean value of SOC under all the forests was decreasing with a rate of $2.4 \mathrm{Mg} \mathrm{C} \mathrm{ha-1}$ per every $20 \mathrm{~cm}$ soil depth (Table 2). The average SOCS up to $60 \mathrm{~cm}$ layer under different forests was ranged from 34.6 to $1549.3 \mathrm{Gg}$ C with highest 
(1549.3 Gg C) under Deodar and lowest (34.6 Gg C) under Northern dry mixed deciduous forests. The total SOC stock of different forest was recorded to the tune of $3344.2 \mathrm{Gg} \mathrm{C}$ of the soil. The variability in SOC depending on land use pattern, management practice, vegetation type, landscape, anthropogenic disturbances and climate.

\section{DISCUSSION}

The significantly highest amount of SOC content was recorded under the northern dry mixed deciduous forest of Kataula followed by that of Tattapani location. It was also observed that the SOC was decreased continuously with depth under these. This may be due to that these forests show least mitigation potential and there is the continuous addition of higher quantities of plant litter, roots and other biomass to the surface may lead to a higher organic carbon content to upper depth than that of the lower depth. Similar, results were obtained by Panwar and Gupta ${ }^{[18]}$; Kaushal ${ }^{[19]}$ and Bhola ${ }^{[20]}$ in the northern dry mixed deciduous forest of Himachal Pradesh. The lowest SOC content was observed in the forest of Pandoh. The data indicated that SOC distribution pattern varies significantly with soil depth. On an average, among all the forests the amount of soil organic carbon was found highest in the uppermost soil layer and it was continuously decreasing with increasing soil depth under all the forest types and the decreasing rate was highly significant. Similar results were obtained by Reddy and Gupta [21]; Bhoumik and Totey ${ }^{[22]}$ under different forest types.

The highest value of Bulk density was recorded under Himalayan Chir pine forest of Pangna followed by Kharsi location and lowest under Khaliyar location. The present findings confirmed with the observations of Shah et al. [23] which showed an increase of bulk density with increasing depth. The interaction effect of location and depths was found statistically non-significant. The descending trend in soil bulk density among different forest was observed as $F_{7}>F_{6}>F_{3}>F_{4}>F_{2}>F_{1}$ and $F_{5}$. The soil bulk density was showing a continuously highly significant increasing trend with depth under all the selected forests which indicated that the soil quality decreased with depth ${ }^{[24]}$. These results were endorsed by Karan et al. ${ }^{[25]}$ and Cihacek and Ulmer ${ }^{[26]}$.

Up to $60 \mathrm{~cm}$ depth the highest coarse fragments were found under Mohru Forest followed by Northern dry mixed deciduous forest and the lowest under Ban oak forest followed by Deodar forest which was at par with Kharsu forest. A descending order of different forest like $F_{6}>F_{7}>F_{2}>F_{3}>F_{5}>F_{1}>F_{4}$ was observed in respect of coarse fragments. Stoniness regarded as the greatest uncertainty in SOC stock estimates ${ }^{[27]}$. Similar results were obtained by Anu ${ }^{[28]}$ with depths.

Forests are the wide-ranging carbon pool on earth which acts as a considerable source and sinks of carbon in nature ${ }^{[29]}$. Thus, it has the prospective to form most important constituents to combat global warming, and adapt to climate change. Forest carbon stock estimation allows the amount of carbon loss during deforestation to be calculated as the amount of carbon that a forest can store when those forests are regenerated. Exact estimation of SOC stocks is important in order to understand the connection between atmospheric and terrestrial carbon ${ }^{[30]}$. The higher SOC content of Kharsu forest than that of Deodar forest might be due to change in climatic conditions at higher elevation ${ }^{[31]}$. The high SOC content under deodar forests as compare to Blue pine, ban, chir, mohru and mixed dry deciduous forest may be attributed to minimum anthropogenic disturbances than that of other forests. The high SOC may also be ascribed to the high tree density and accumulation of more leaf litter which showed consonance with the finding of Zegeye ${ }^{[32]}$; Kater et al. ${ }^{[33]}$. The interconnection between forest types and depth was found to exert statistically significant influence on SOC content. The mean value of SOC under all the forests was decreasing with soil depth. The average soil organic carbon stock up to $60 \mathrm{~cm}$ layer under different forests was highest under Deodar and lowest under Northern dry mixed deciduous forests. Similar results were obtained by Minj ${ }^{[34]}$. The descending trend SOC like: $F_{5}>$ $F_{1}>F_{4}>F_{2}>F_{3}>F_{6}>F_{7}$ was observed among different forests which may be due to variability land use pattern and management practices ${ }^{[35]}$.

\section{CONCLUSIONS}

The order followed by bulk density under different forests was as Mohru > Northern dry mixed deciduous > Chir pine $>$ Ban oak $>$ Blue pine $>$ Deodar $>$ Kharsu forests by coarse fragments as Mohru $>$ Northern dry mixed deciduous forest $>$ Blue pine $>$ Chir pine forest $>$ Kharsu forest $>$ Deodar forest $>$ Ban oak forest. The highest SOC stock was found in Deodar forests and in northern dry mixed deciduous forests. The deodar forests contribute highest in SOC pool followed by chir pine, blue pine, ban 
oak, Kharsu, Mohru oak and northern dry mixed deciduous forests respectively. Soil organic carbon stock followed an order as Kharsu $>$ Deodar $>$ Ban $>$ Blue pine $>$ Chir pine > Mohru >Northern dry mixed deciduous forest. We suggest measuring the fine soil stock of a certain soil layer for future studies which is to be multiplied with its SOC material to obtain unbiased SOC stock estimates. When measuring rock pieces, SOC stocks of existing datasets may also be recalculated in the case of re-sampling.

The study might be useful for the better management of soil and forests and Assessment of the potential for mitigation of agricultural practices at industry, area or farm level particularly in the study area and as a whole state in general.

\section{ACKNOWLEDGMENTS}

Authors are very thankful to the Prof \& Head Department of Environmental Science, YSP UHF for the proving facilities in the laboratory.

\section{CONTRIBUTION OF AUTHORS}

Research concept- Dr. Mohan Singh Jangra, Dr. SK Bhardwaj

Research design- Dr. Mohan Singh Jangra, Dr. SK Bhardwaj

Supervision- Dr. Mohan Singh Jangra

Materials- Vijeta Thakur, Dr. Mohan Singh Jangra

Data collection- Vijeta Thakur

Data analysis and interpretation- Vijeta Thakur, Dr. Mohan Singh Jangra

Writing article- Dr. Mohan Singh Jangra, Vijeta Thakur

Article review- Dr. Mohan Singh Jangra

Article editing- Dr. Mohan Singh Jangra

Final approval- Dr. Mohan Singh Jangra

\section{REFERENCES}

[1] Eswaran H, Reich PF, Kimble JM, Beinroth FH, Padmanabhan $E$, et al. Global climate change and pedogenic carbonates. Lal R (Ed). Lewis Publishers, USA pp., 1999; 15-25.

[2] Dey SK. A preliminary estimation of carbon stock sequestrated through rubber (Hevea brasiliensis) plantation in North Eastern regional of India. Indian Forester, 2005; 131(11): 1429-36.

[3] Prentice IC, Farquhar GD, Fasham MJR, Goulden ML, Heimann $M$, et al. The carbon cycle and atmospheric carbon dioxide. Climate Change: The Scientific Basis
IPCC. Cambridge Univ Press Cambridge UK, 2001; pp. 185-237.

[4] Whitehead D. Forests as carbon sinks-benefits and consequences. Tree Physiol., 2011; 31: 893-902.

[5] Lal R. Forest soils and carbon sequestration. Forest Ecol Manag., 2005; 220: 242-58.

[6] Peltoniemi M, Thurig E, Ogle S, Palosuo T, Schrumpf $\mathrm{M}$, et al. Models in country scale carbon accounting of forest soils. Silva Fennica., 2007; 41: 575-602.

[7] Johnson DW, Curtis PS. Effects of forest Manag. on soil $\mathrm{C}$ and $\mathrm{N}$ storage: meta-analysis. Forest Ecol Manag., 1991; 140: 227-38.

[8] Yanai RD, Arthur MA, Siccama TG, Federer CA. Challenges of measuring forest floor organic matter dynamics: repeated measures from a chronosequence. Forest Ecol Manag., 2000; 138: 273-83.

[9] Fahey TJ, Groffman PM, Holmes RT, Schwarz PA, Siccama TG, et al. The biogeochemistry of carbon at Hubbard Brook. Biogeochem., 2005; 75: 109-76.

[10]Negi SS, Gupta MK, Sharma SD. Sequestered organic carbon pool in the forest soils of Uttarakhand State, India. Int J Sci Environ Technol., 2013; 2(3): 510-20.

[11]Yuan Z, Antonio G, Fei L, Ji Y, Shuai S, et al. Soil organic carbon in an old-growth temperate forest: Spatial pattern, determinants and bias in its quantification. Geoderma, 2013; 195(196): 48-55.

[12] Ellert BH, Janzen HH, Entz T. Assessment of a method to measure temporal change in soil carbon storage. Soil Sci Soc Am J., 2002; 66: 1687-95.

[13]De Vries. Intensive monitoring of forest ecosystems in Europe: 2: Atmospheric deposition and its impacts on soil solution chemistry. Forest Ecol Manag., 2003; 174(1): pp. 97-115.

[14]Amichev B, Galbraith JM. A revised methodology for estimation of forest soil carbon from spatial soils and forest inventory data set. Environ Manag., 2004; 33: pp. 74-86.

[15]Balamurgan J, Kumar K, Rajarajan A. Effects of Eucalyptus Citridora on the Physical and Chemical Properties of Soils. J Indian Soc Soil Sci., 2000; 48: pp. 491-95.

[16]Gelman F, Binstock R, Halicz L. Application of the Walkley-Black titration for the organic carbon quantification in organic rich sedimentary rocks. Fuel, 2012; 96: 608-610. 
[17]Gomez KA, Gomez AA. Statistical Procedures for Agricultural Research $\left(2^{\text {nd }}\right.$ ed.), John Wiley and Sons Inc, New York, USA, 1984; pp. 680.

[18]Panwar VP, Gupta MK. Soil Organic Carbon pool under different forest types in Himachal Pradesh. Int J Farm Sci., 2013; 3: 81-89.

[19]Kaushal R. Fertility status and moisture retention characteristics of forest soils of dry zone deodar (Cedrus deodara) ecosystem. M Sc Thesis. Dr Y S Parmar University of Horticulture and Forestry, Nauni, Solan, (HP), India, 1992; pp. 95.

[20]Bhola N. Studies on relative growth performance and soil enrichment potential of some nitrogen fixing trees. M Sc Thesis. Dr Y S Parmar University of Horticulture and Forestry, Nauni, Solan, (HP), India, 1995; pp. 94.

[21]Reddy M C, Gupta B. Soil Organic Carbon Stocks under Different forest types of Himalayan moist temperate forests in Shimla District, Himachal Pradesh, India. Int J Agric Sci Res., 2018; 8: pp. 1-8.

[22]Bhoumik AK, Totey NG. Characteristics of some soils under teak forests. J Ind Soc Soil Sci., 1990; 33: pp. 945-947.

[23]Shah S, Sharma DP, Pala NA, Tripathi P, Dar A. Carbon stock and densities of soils under chir pine (Pinus roxburghii Sargent) forests of Solan forest Division, Himachal Pradesh. Indian J Soil Conserv., 2013; 41: 279-86.

[24]Post WM, Kwon KC. Soil carbon sequestration and land-use change: processes and potential. Global Change Biol., 2000; 6: 317-27.

[25]Karan S, Bhandari AR, Tomar KP. Morphology, genesis and classifications of some soils of North Western Himalayas. J Indian Society Soil Sci., 1991; 39: 139-46.

[26]Cihacek $L$, Ulmer MG. Effect of tillage on profile soil carbon distribution in the northern Great Plains of the U.S. In: R. Lal, J. Kimble, E. Levine, and B.A. Steward (eds.). Soil Manag. and Greenhouse Effect. C R C Press. Boca Raton, 1998; pp. 83-91.
[27]IPCC. Good practice guidance for land use, land-use change and forestry, Good practice guidance for land use, land-use change and forestry, http://www.ipccnggip.iges.or.jp/ public/gpglulucf/ gpglulucf.html, 2003.

[28]Anu K. Quantification of Soil Organic Carbon Stock of Forests in Solan District of Himachal Pradesh. MSc Thesis. Department of Environmental Science. Dr. Y.S. Parmar University of Horticulture Forestry, Nauni, Solan (H.P). India, 2011; pp. 46.

[29]Vashum KT, Jayakumar S. Methods to Estimate Above Ground Biomass and Carbon Stock in Natural Forests- A Review. J Ecosystem Ecography, 2012; 2: pp. 116.

[30]Thakur V, Singh M, Bhardwaj SK. Forest types and soil characteristics- a review. Int J Innov Sci Res Rev., 2020; 2(5): 201-05.

[31] Kanagraj N, Kaleeswari NK and Tilak KM. Impact of Altitudes on Soil Characteristics in Dry Deciduous Forest Ecosystem, Western Ghats, Tamil Nadu, India. Int J Curr Microbiol Appl Sci., 2017; 6: 2218-24.

[32]Zegeye MW. Tree crop interaction studies in agrihorti-silviculture system. M Sc Thesis. Dr YS Parmar University of Horticulture and Forestry, Nauni, Solan, (HP), India, 1999; pp. 65.

[33]Kater LM, Kanta S, Budelman A. Karite (Vilellaria paradoxa) and neke (Parkia High lohosa) associated with crops in south mali. Agroforestry Systems, 1992; 18: 89-105.

[34]Minj AV. Carbon sequestration potential of agroforestry systems- An evaluation in low and mid hills of western Himalaya. PhD Thesis. Department of Silviculture and Agroforestry. $\mathrm{Dr}$ YS Parmar University of Horticulture and Forestry, Nauni, Solan, (HP), India, 2008; pp. 124.

[35]Sharma PK, Verma TS, Bhagat RM. Soil structure improvement with the addition of Lantana camara biomass in rice, wheat cropping. Soil Use Manag., 1995; 11: 199-203. 